\title{
Oral Health Status among Tobacco Users of Selected Rural Population
}

Uddin $\mathrm{ANMM}^{1}$, Jewel $\mathrm{MH}^{2}$

DOI: https://doi.org/10.3329/jafmc.v14i2.45895

\begin{abstract}
Introduction: Tobacco smoking is a major risk factor for the development of oral cancer in developing countries. The prevalence of tobacco use is the highest amongst poor people of low educational background. Cancer of oral cavity is the commonest cancer in our country and ranked 5th among male and 4 th in female.
\end{abstract}

Objectives: To assess the oral health status among tobacco users in a selected rural population of Dhamrai and Saturia Upazilla in Dhaka district.

Materials and Methods: This descriptive cross sectional study was conducted from 1 st November 2018 to 15th January 2019. Non-probability purposive sampling was done and data was collected from 445 respondents.

Results: Among the respondents, $26 \%$ were day laborer and $24 \%$ were businessmen with family income were between Tk 5000-Tk 10000. About $78.65 \%$ of the respondents have tobacco smoking habit among them $75 \%$ had current tobacco chewing habit as jarda. $69.21 \%$ of the respondents did not complain of any oral problems. Oral health status among the current tobacco smokers and chewers showed that they had dental stain $(90.78 \%)$, dental plaque $(65.17 \%)$, dental calculus (44.49\%), dental carries (53.03\%), bad breathing smell (75\%), soft tissue inflammation $(23.82 \%)$, loose teeth $(26.74 \%)$ and ulceration $(8.54 \%)$ in their oral cavity.

Conclusion: Tobacco control protects the rights and health of non-smokers, specially babies, children, youth and pregnant women. The dangers posed to oral health from smoking and chewing tobacco are well documented but the lack of knowledge of the risks is a concern. So oral health should be given great importance from childhood and dental checkup should be done regularly. The general people should be made aware of it through various mass media.

Key-words: Rural population, Oral Health, Tobacco users.

\section{Introduction}

Tobacco use is a global epidemic among common people. As with adults, it poses a serious health threat to youth and young adults. Tobacco use diminishes the immune response leading to oral infection, retards healing process following surgical and accidental wounding and promotes periodontal degeneration ${ }^{1}$. Nearly $75 \%$ of male smokers live in developing countries $50 \%$ of female smokers live in developed countries ${ }^{2}$. Cancer of the oral cavity is the eighth most common cancer in the world among men in developing countries, particularly in areas of South Central Asia where cancer of the oral cavity is among the three most frequent types of cancer ${ }^{3,4,5}$. Tobacco smoking practice is believed to have begun as early as $5000-3000$ BC in Mesoamerica and South America ${ }^{6}$.

Fresh leaves of plants in the genus Nicotiana processed to tobacco containing higher concentrations of nicotine used in the form of bidi, cigarette, pipe, pan, guhtka which is the major preventable cause of premature death and of several general diseases in the mouth ${ }^{7,8}$. The general and oral health of future generations are deteriorating due to increasing number of smokers and smokeless tobacco users among young people in different areas of the world. Tobacco use is highest amongst people of low educational background and the poor in most countries ${ }^{9}$. Three fourth of head and neck cancers are found in the oral cavity and oropharynx in the form of squamous cell carcinoma usually begin as leukoplakia, erythroplakia and erythroleukoplakia ${ }^{10}$. Oral cancer is one of the few cancers whose survival rate has not improved over last few decades among the adults under the age of forty years ${ }^{11}$. In Bangladesh, most of the population is unaware of hazards related to tobacco consumption ${ }^{12}$. Smokeless tobacco has been implicated as an added risk factor for numerous oral conditions. Oral cancer is the third most common cancer in Asia due to the habit of smokeless tobacco eating behavior with betel nut. Oral cancer is the sixth most common malignant tumor for both genders now a days ${ }^{13}$. Staining of teeth, decreased ability to taste and smell, nicotinic stomatitis and keratosis are common reversible oral conditions among smokeless and smoked tobacco users ${ }^{14-16}$.

\section{Materials and Methods}

This cross sectional descriptive study was carried out to assess the oral health status among tobacco users in a selected rural population of Dhamrai and Saturia upazilla in Dhaka district from November 2018 to January 2019. Non probability purposive sampling was done and data was collected from 445 respondents. Data were documented in the master sheet and analyzed using SPSS 17.0 for Windows. Data were presented in the form of tables and diagram after correction and analysis.

\section{Results}

Among the total 445 respondents $39.55 \%$ were of the age of $35-54$ years, $89.43 \%$ were married, $84.71 \%$ were male and 
$87.64 \%$ were Muslim. Most of the respondents (51.92\%) were literate and among them $15.95 \%$ had secondarylevel education and only $11.23 \%$ completed graduation. About $26 \%$ of respondents were day labourer $56 \%$ lived in a nuclear family, $33.25 \%$ had family income ranging from Tk 5000-Tk1000 (Table-I). About $78.65 \%$ of the respondents were current smokers and $39.47 \%$ of them smoked less than 5 sticks a day and $31.14 \%$ of the respondents smoked tobacco for 15-29 years (Table-I). About $68 \%$ smoked cigarette (Figure-1). About $75 \%$ of the respondents consumed tobacco in the form of jorda (Figure-2). Among the 445 respondents $69.21 \%$ did not complain of any oral problems but on examination, $90.78 \%$ of them had dental stain and $75 \%$ had bad breath alongside other oral health problems (Table-III).

Table-I: Distribution of study population by demographic and socio-economic characteristics $(n=445)$

\begin{tabular}{|c|c|c|c|}
\hline \multirow[b]{3}{*}{ Sex } & Variables & Frequency & Percentage \\
\hline & Male & 377 & 84.71 \\
\hline & \begin{tabular}{|l|} 
Female \\
\end{tabular} & 68 & 5.28 \\
\hline \multirow{5}{*}{ Age in years } & $15-34$ & 98 & 22.02 \\
\hline & $35-54$ & 176 & 39.55 \\
\hline & $55-74$ & 152 & 34.15 \\
\hline & $>75$ & 19 & 4.26 \\
\hline & \multicolumn{3}{|c|}{ Mean \pm SD $=35.79 \pm 11.73$} \\
\hline \multirow[b]{2}{*}{ Religion } & Muslim & 390 & 87.6 \\
\hline & \begin{tabular}{|l} 
Hinduism \\
\end{tabular} & 55 & 12.4 \\
\hline \multirow{5}{*}{ Education } & Primary & 89 & 20.34 \\
\hline & Secondary & 107 & 24.03 \\
\hline & HSC/Equivalent & 20 & 4.49 \\
\hline & Graduate & 50 & 11.23 \\
\hline & \begin{tabular}{|l} 
Illiterate/ literate \\
\end{tabular} & 214 & 48.08 \\
\hline \multirow{7}{*}{ Occupation } & Student & 9 & 2 \\
\hline & Service & 53 & 12 \\
\hline & Business & 107 & 24 \\
\hline & Agri-worker & 80 & 18 \\
\hline & Day labourer & 116 & 26 \\
\hline & \begin{tabular}{|l} 
Housewife \\
\end{tabular} & 36 & 8 \\
\hline & Aged/Retired & 44 & 10 \\
\hline \multirow{2}{*}{ Marital status } & Unmarried & 22 & 4.94 \\
\hline & Married & 398 & 89.43 \\
\hline
\end{tabular}

Table-II: Distribution of respondents by tobacco smoking related information

\begin{tabular}{|c|c|c|c|}
\hline \multicolumn{2}{|c|}{ Tobacco Smoking related characteristics } & Frequency & Percentage \\
\hline \multirow{4}{*}{ Tobacco smoking habit } & Current & 350 & 78.65 \\
\hline & Former & 36 & 8.70 \\
\hline & Others(Non-smoke) & 59 & 12.96 \\
\hline & Total & 445 & 100 \\
\hline \multirow{6}{*}{$\begin{array}{l}\text { Number of sticks } \\
\text { smoking per day }\end{array}$} & $\leq 5$ & 99 & 29.47 \\
\hline & $6-10$ & 96 & 28.47 \\
\hline & $11-15$ & 39 & 9.60 \\
\hline & \begin{tabular}{|l|}
$16-20$ \\
\end{tabular} & 58 & 15.89 \\
\hline & $>20$ & 58 & 16.56 \\
\hline & Total & 350 & 100 \\
\hline \multirow{6}{*}{$\begin{array}{l}\text { Duration of tobacco } \\
\text { smoking in years }\end{array}$} & $0-14$ & 97 & 27.71 \\
\hline & \begin{tabular}{|l|}
$15-29$ \\
\end{tabular} & 103 & 31.14 \\
\hline & $30-44$ & 72 & 20.57 \\
\hline & $45-59$ & 72 & 20.57 \\
\hline & $>60$ & 6 & 1.71 \\
\hline & \begin{tabular}{|l|} 
Total \\
\end{tabular} & 350 & 100 \\
\hline
\end{tabular}

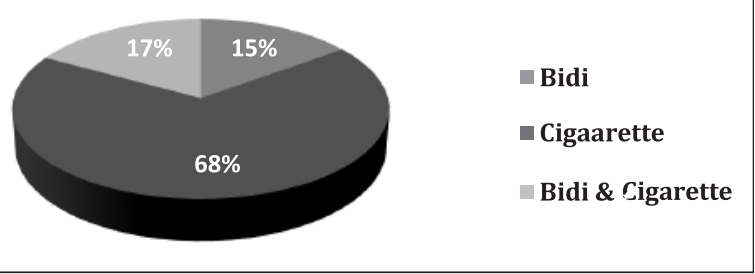

Figure-1: Types of tobacco smoked

Table-III: Distribution of respondents by tobacco chewing related information

\begin{tabular}{|l|l|r|r|}
\hline \multicolumn{2}{|c|}{ Characteristics } & Frequency & Percentage \\
\hline \multirow{4}{*}{ Tobacco chewing habit } & Current & 266 & 92.04 \\
\cline { 2 - 4 } & Former & 23 & 7.95 \\
\cline { 2 - 4 } & Total & 289 & 100 \\
\hline \multirow{5}{*}{$\begin{array}{l}\text { Duration of tobacco chewing } \\
\text { in years }\end{array}$} & $\leq 5$ & 69 & 25.94 \\
\cline { 2 - 4 } & $6-10$ & 40 & 15.04 \\
\cline { 2 - 4 } & $11-15$ & 32 & 12.03 \\
\cline { 2 - 4 } & $16-20$ & 28 & 10.53 \\
\cline { 2 - 4 } & $21-25$ & 19 & 7.14 \\
\cline { 2 - 4 } & $\geq 26$ & 78 & 29.32 \\
\cline { 2 - 4 } & Total & 266 & 100 \\
\hline
\end{tabular}

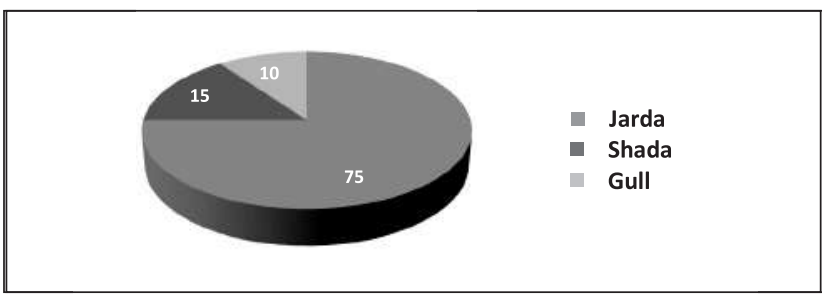

Figure-2: Types of tobacco chewing

Table-IV: Distribution of respondents by oral health related problems $(n=445)$

\begin{tabular}{|l|l|c|c|}
\hline \multicolumn{2}{|c|}{ Oral health Problems } & Frequency & Percentage \\
\hline \multirow{4}{*}{$\begin{array}{l}\text { Complaining } \\
\text { oral problem }\end{array}$} & Yes & 137 & 30.78 \\
\cline { 2 - 4 } & No & 308 & 69.21 \\
\cline { 2 - 4 } & Total & 445 & 100 \\
\hline \multirow{4}{*}{$\begin{array}{l}\text { On examination } \\
\text { oral health } \\
\text { status of } \\
\text { tobacco users }\end{array}$} & Bad breath & 334 & 75 \\
\cline { 2 - 4 } & Dental stain & 404 & 90.78 \\
\cline { 2 - 4 } & Dental plaque & 290 & 65.17 \\
\cline { 2 - 4 } & Dental calculus & 198 & 44.49 \\
\cline { 2 - 4 } & Dental caries & 236 & 53.03 \\
\cline { 2 - 4 } & Gum and soft tissue inflammation/pain & 106 & 23.82 \\
\cline { 2 - 4 } & Loose teeth & 119 & 26.74 \\
\cline { 2 - 4 } & Leukoplakia & 33 & 7.14 \\
\cline { 2 - 4 } & Erythroplakia & 20 & 4.5 \\
\cline { 2 - 4 } & Ulceration & 38 & 8.54 \\
\hline
\end{tabular}

${ }^{*}$ Multiple responses

\section{Discussion}

In this study about $42.97 \%$ of the respondents was illiterate and $56.15 \%$ took formal education. Among them, 27.02\% have got primary level education. This study result does not accord with Jabeen et al, where $35.8 \%$ were illiterate and $32 \%$ had secondary level education ${ }^{18}$. This study shows that $87.64 \%$ of the respondents belonged to Muslim religion and the rest $(23 \%)$ belonged to Hindu religion whereas in the 
study on Oral health status among the adult tobacco users in Bangladesh: conducted by Kabir et al shows that majority (94.2\%) of the respondents were Muslim that accords with our study ${ }^{17,19}$. Respondents occupational status shows that among 370 respondents majority were either businessmen $42 \%$ or agricultural worker (20\%). This finding is similar with the study Jabeen et al where majority $51 \%$ of the males were either businessmen or agricultural workers. But this study does not accord with the study on Prevalence and trends of cigarette smoking in different occupational groups that shows that the prevalence of current smokers ranged from 23(professional) to $57 \%$ (service occupations) in men and from 15 (artists and writers) to 59 (repair and craft occupations) in women ${ }^{18,19}$.

Among 370 respondents, majority (83\%) were current smokers and among them $100 \%$ were male. This finding does not accord with the findings of the Jabeen et al where only $33.2 \%$ respondents were currents smokers and the rest $66.8 \%$ were currently ${ }^{18}$ non-smokers and among the current tobacco smokers almost all were male $98.3 \%$. This study shows that there is marked consumption of tobacco mainly in the age group of 35-54 years. But the study in Central India shows that there is marked consumption $72 \%$ of tobacco and associated products among the geriatric population (60 years \& above $)^{20}$. Among the current smokers, $75 \%$ smoke tobacco in cigarette form and $16 \%$ smoke it as bidi. Smoking was found to be $21-56 \%$ among men in South Asian countries with very little information available about women. Another study of Al Haddad et al shows that Cigarettes 21\% water pipes $13.0 \%$ and cigars $1.6 \%$ were popular. Another study shows that $71.3 \%$ subjects consumed tobacco in the form of betel quid or khaini and $63.3 \%$ males were tobacco smokers in the form of cigarettes and bidis ${ }^{21-23}$.

These study shows $43.24 \%$ of respondents belong to the age group of $35-54$ years and $33.18 \%$ are smoking tobacco for duration of 11-20 years, whereas in a study of Jamnagar District states adolescents were in the age group of 17-19 years and they were addicted for more than 12 months. Another study by Kabir et al shows $46.8 \%$ respondents use tobacco for the duration of more than 5 years, $33.6 \%$ and $19.4 \%$ use tobacco for the duration of 1-5years and less than 1 year respectively ${ }^{24,19}$. A study among adult Bangladeshi population showed where current smoking and gul usage were significantly higher in males $42.2 \%$ than females $2.3 \%$ while chewing tobacco was more common in females $21.6 \%$. On average a smoker consumed 9.3 sticks a day with males, which also supports this study where $83 \%$ of the respondent were current smokers, male respondents were $87 \%$ and $17 \%$ respondents uses less than 5 stick per day. Another study shows that $31.5 \%$ take up to 5 cigarettes per day; $13.6 \%$ and $15.7 \%$ take $6-10$ cigarettes, more than 10 cigarettes per day respectively ${ }^{19}$.

This study result revealed that there were dental stain $90.78 \%$, dental plaque $65.17 \%$, dental calculus $44.49 \%$, dental carries $53.03 \%$, bad breathing smell $75 \%$, soft tissue inflammation $23.28 \%$, loose tooth $26.74 \%$, leukoplakia $7.14 \%$, Erythroplakia $4.5 \%$ and ulceration $8.54 \%$ were present in $30.78 \%$ respondents' oral cavity (Table-IV) whereas, Jabeen et al shows that $95 \%$ of the tobacco consumers had dental stain, $73 \%$ had dental plaque, $66 \%$ had dental calculus, $59 \%$ had dental caries, $27 \%$ had soft tissue swelling, $15 \%$ had Leukoplakia, $4 \%$ had Erythroplakia and $5 \%$ had ulceration in their oral cavity that almost accords with our study findings ${ }^{17-19}$.

\section{Conclusion}

The dangers posed to oral health from smoking and chewing tobacco are well documented but the lack of knowledge of the risks is a concern. So oral health should be given great importance from childhood and dental checkup should be done regularly. The general people should be made aware of it through various mass media. Tobacco control protects the rights and health of non-smokers, specially babies, children, youth and pregnant women. Oral health should be given great importance from childhood and dental checkup should be done regularly. The general people should be made aware of it through various mass media.

\section{References}

1. World Health Organization. World Oral Health Report 2003.

2. The Tobacco Atlas, 6th edition. Available athttps://files. tobaccoatlas.org/wpcontent/uploads/2018/03/TobaccoAtlas_ 6thEdition_LoRes.pdf

3. Jensen EJ and Overgaard E. Smoking patterns, knowledge of tobacco related health effects and desires to quit am006Fing 1417- year-old boarding school pupils in Denmark, 1987-90. Tobacco Control 1993; 2:296-99.

4. Jiloha CR. Biological basis of tobacco addiction: Implications for smoking-cessation treatment Indian J Psychiatry 2010; 52(4):301-7.

5. Reibel J. Tobacco and oral diseases. Update on the evidence, with recommendations. Medical Principles and Practice 2003; 12:22-32.

6. Gatelyl. Tobacco: A Cultural History of How an Exotic Plant Seduced Civilization. Diane 2004:3-7.

7. Johnson NW, Bain C. Tobacco and oral disease. EU-Working Groupon Tobacco andOral Health. Brit Dent J 2000; 189:200-6.

8. Reibel J. Tobacco andoral diseases: Anupdate on the evidence, with recommendations. Med Princ Pract 2003; 12(sppl 1):22-32.

9. https://www.who.int/oral_health/action/risks/en/index2.html.

10. Silverman S. Demographics and occurrence of oral and pharyngeal cancers: The outcomes, the trends, the challenge. J Am Dent Assoc2001; 132(suppl):75-165.

11. Myers JN, Elkins T, Roberts D et al. Squamous cell carcinoma of the tongue in young adults: Increasing incidence and factors 
that predict treatment outcomes. Otolaryngology Head Neck 2000; 122(1):44-18.

12. Rahman M, Sakamoto J, Fukui T. Bidi smoking and oral cancer: A meta-analysis. Int J Cancer 2003; 106(4):600-4.

13. Johnson N. Tobacco use and oral cancer: A global perspective. J Dent Educ 2001; 65(3):328-39.

14. Asmussen E, Hansen EK. Surface discoloration of restorative resins in relation to surface softening and oral hygiene. Scand J Dent Res 1986; 94:174-7.

15. Mehta FS, Jalnawalla PN, Daftary DK et al. Reverse Smoking in Andhra Pradesh, India: Variability of clinical and histologic appearances of palatal changes. Int J Oral Surg 1977; 6:75-83.

16. Hedin CA, Pindborg JJ, Axell T. Disappearance of smoker's melanosis after reducing smoking. J Oral Pathol Med 1993; 22:228-30.

17. Sankaranarayanan R, Duffy SW, Padmakumary G. Tobacco chewing, alcohol and nasal snuff in cancer of the gingiva in Kerala, India. Br J Cancer 1989; 60:638-43.
18. Jabeen S, Manni UJA, Shakil SS. Oral health status among tobacco users in the selected rural population. Bangladesh Med J 2014; 43(2):79-83.

19. Kabir M, Arafat M. oral health condition among users and nonusers attending the outpatient department of Pioneer Dental College, Bangladesh Journal of Dental Research \& Education 2011; 1(1):28-31.

20. Khanna $S$. The interaction between tobacco use and oral health among tribes in central India Tobacco Induced Diseases 2012; 10(1):16.

21. Rahman M, Fukui T.Bidi smoking and health. Public Health 2000; 114(2):123-7.

22. Al Haddad N, Hamadeh RR. Smoking among secondary-school boys in Bahrain: Prevalence and risk factors. East Mediterr Health J 2003; 9(1/2):78-86.

23. Khandekar SP, Bagdey PS, Tiwar RR. Oral Cancer and Some Epidemiological Factors: A Hospital Based Study. Indian Journal of Community Medicine 2006; 31(3):157-9.

24. Makwana NR, Shah VR, Yadav S. A Study on Prevalence of Smoking and Tobacco Chewing among Adolescents in rural areas of Jamnagar District, Gujarat State. J Med Sci Res 2007; 1:47-9 